\title{
Prevalence of Systemic Arterial Hypertension and Associated Factors Among Adults from the Semi-Arid Region of Pernambuco, Brazil
}

\author{
Emerson Rogério Costa Santiago, ${ }^{1}{ }^{\circledR}$ Alcides da Silva Diniz, ${ }^{1}$ Juliana Souza Oliveira, ${ }^{2}$ Vanessa Sá Leal, ${ }^{2}$ Maria Izabel \\ Siqueira de Andrade, ${ }^{1}$ Pedro Israel Cabral de Lira ${ }^{1}$ \\ Universidade Federal de Pernambuco - Programa de Pós-graduação em Nutrição, ${ }^{1}$ Recife, PE - Brazil \\ Universidade Federal de Pernambuco - Núcleo de Nutrição, ${ }^{2}$ Vitória de Santo Antão, PE - Brazil
}

\begin{abstract}
Background: Systemic arterial hypertension is a substantial public health problem responsible for millions of deaths per year worldwide. However, little is known about the epidemiology of this disease in areas distant from large urban centers in Brazil. Such information is necessary to plan health promotion strategies.

Objective: To estimate the prevalence of hypertension and determine its associated factors in adults residing in the semi-arid region of the state of Pernambuco, Northeastern Brazil.

Method: This is a cross-sectional study conducted with a random sample of male and female adults. Individuals with systolic blood pressure $\geq 140 \mathrm{~mm} / \mathrm{Hg}$ and/or diastolic blood pressure $\geq 90 \mathrm{~mm} / \mathrm{Hg}$ and those who reported being under treatment with antihypertensive drugs were considered hypertensive. We collected data on demographic, socioeconomic, behavioral, and anthropometric characteristics, as well as health and nutrition. The statistical analysis used Pearson's chi-square test, the chi-square test for trend, and multivariate Poisson regression analysis. A p-value $<0.05$ in the final model was considered indicative of statistical significance.
\end{abstract}

Results: The sample consisted of 416 individuals, and the prevalence of hypertension was $27.4 \%(95 \% \mathrm{Cl} 23.2-32.0)$. In the final model, the independent predictors of hypertension were age of 40 years or older $(p=0.000)$, low economic class $(p=0.007)$, smoking $(p=0.023)$, overweight determined by the body mass index $(p=0.003)$, and reduced glucose tolerance/diabetes mellitus $(p=0.012)$.

Conclusion: The prevalence of hypertension was high and related to important risk factors. Thus, prevention and control strategies are recommended. (Arq Bras Cardiol. 2019; 113(4):687-695)

Keywords: Hypertension/prevention and control; Prevalence; Cardiovascular Diseases; Epidemiology; Blood Pressure; Risk Factors.

\section{Introduction}

Systemic arterial hypertension is a substantial public health problem around the world and the most common clinical condition found in primary care. ${ }^{1,2}$ This condition is responsible for approximately 9.4 million deaths per year worldwide. ${ }^{3}$ It is not only one of the major risk factors for other cardiovascular diseases, ${ }^{2}$ but also a syndrome with its manifestations, characteristics, and multifactor etiology. ${ }^{4}$

The prevalence of hypertension increased from approximately $25.9 \%$ of the global adult population at the beginning of the $21^{\text {st }}$ century to $31.1 \%$ in 2010 , a $5.2 \%$ increase in ten years. ${ }^{5}$ In developed countries, however, a

Mailing Address: Emerson Rogério Costa Santiago •

Universidade Federal de Pernambuco - Programa de Pós-graduação em Nutrição - Av. Prof. Moraes Rêgo, 1235. Postal Code 50670-901, Recife, PE - Brazil

E-mail: emersoncostasantiago@gmail.com

Manuscript received July 03, 2018, revised manuscript November 18, 2018, accepted January 23, 2019

DOI: $10.5935 / a b c .20190145$
$2.6 \%$ reduction occurred in this period, whereas developing countries faced a $7.7 \%$ increase. ${ }^{5}$ In Brazil, studies compiling data from several cities report that hypertension affects approximately $30 \%$ of the adult population, corresponding to 36 million individuals. $4,6,7$

Analyzing the distribution of the disease in the country, the north and northeast regions have the lowest rates of hypertension. ${ }^{8}$ However, this type of information is scarce in these regions due to the low number of surveys addressing the epidemiology of this condition. ${ }^{9}$

The semi-arid region covers a large area of Brazil, especially in the northeast part of the country. This region is often hit by crises related to long periods of drought. Besides the low socioeconomic development of the region, this situation can contribute to an increase in chronic non-communicable diseases. ${ }^{10,11}$ Nevertheless, little is known about the epidemiology of hypertension and its geographic distribution in populations living distant from large Brazilian urban centers and in mesoregions, such as the semi-arid region.

Considering the need for information that can assist in improving and optimizing public health services and actions, the present study aimed to estimate the prevalence 
of hypertension and determine its associated factors in the adult population from the semi-arid region of the state of Pernambuco, Northeastern Brazil.

\section{Methods}

This is a population-based cross-sectional study conducted with male and female adults (aged 20 to 59 years) residing in the semi-arid region of Pernambuco.

The study population was determined by cluster sampling. Pernambuco is subdivided into 12 development regions (DR), six of which correspond to the semi-arid zone. Among them, three were randomly selected in the first stage of the sampling process. Next, one city was chosen from each DR: Serra Talhada (DR 4), Custódia (DR 12), and Belém de São Francisco (DR 1). Next, five census tracts were drawn per city with urban/rural distribution based on data from the 2010 Census. Lastly, 350 households were randomly selected to form a representative sample of the population in the semi-arid region of Pernambuco. The sample comprised all adult residents of the selected homes who were present at the time of data collection. Individuals with any physical limitation that hindered the anthropometric evaluation, debilitating diseases, and who declined to participate were excluded from the study. All stages of the selection process were performed using lists of random numbers generated with the aid of the EPITABLE tool of the Epi Info statistical package, version 6.04 (CDC/WHO, Atlanta, GE, USA).

The fieldwork occurred between July and September 2015 by a team of researchers who had previously undergone training for the administration of data collection instruments. A pilot study was conducted with 30 families in a city not selected for the main study to put into practice the logistics of the fieldwork and test the data collection instruments.

The sample size was calculated a posteriori assuming a 20\% estimated prevalence of hypertension in the northeast region of Brazil, ${ }^{8}$ a 5\% sampling error, a 95\% confidence interval, and a factor of 1.5 to compensate for the design effect of the cluster sampling. Moreover, $10 \%$ was added to compensate for possible dropouts, leading to a total of 410 individuals.

The following demographic and socioeconomic characteristics and respective categories were collected: gender (male or female), age in years (20 to 29,30 to 39 , 40 to 49,50 to 59 ), ethnicity (white or multiracial/black), schooling (never studied, primary school, high school/ university), employment status (works or does not work), and place of residence (urban or rural area). Data collection followed the guidelines of the Instituto Brasileiro de Geografia e Estatística (IBGE - Brazilian Institute of Geography and Statistics). ${ }^{12}$ Economic class was categorized based on the Brazilian Economic Classification Criteria of the Associação Brasileira de Empresas de Pesquisa (ABEP - Brazilian Market Research Association): ${ }^{13}$ upper/middle (A1, A2, B1, B2, C1, C2) and lower (D, E) classes.

We collected the following behavioral characteristics: alcohol intake in the previous 30 days (yes or no); active smoking (smoker/ex-smoker or never smoked); passive smoking (yes or no; individuals who do not actively smoke but are frequently in contact with cigarette smoke from people at home, work, or school/university); and addition of salt to food after preparation (never, sometimes/almost always). Physical activity level was determined using the International Physical Activity Questionnaire (IPAQ) validated for use in Brazil, ${ }^{14}$ which enables the classification of individuals as sedentary/ insufficiently active or active/very active. ${ }^{14}$

Anthropometric data were collected in duplicate following the guidelines of the World Health Organization. ${ }^{15}$ Body mass was measured using a digital scale (TANITA ${ }^{\mathrm{TM}}$, model BF-683 W). Height was measured using a portable stadiometer (Alturaexata ${ }^{\mathrm{TM}}$ ). Waist circumference (WC) was measured at the midpoint between the last rib and the iliac crest with a flexible, non-elastic metric tape $\left(\right.$ Sanny $\left.^{\mathrm{TM}}\right)$. When a difference greater than $0.5 \mathrm{~cm}$ was found between the two height and WC values, the participant was measured a third time, and the two closest results were considered to calculate the arithmetic mean.

The following health and nutritional characteristics and respective categories were collected: body mass index (BMI) (not overweight when $<25 \mathrm{~kg} / \mathrm{m}^{2}$ and overweight when $\geq 25 \mathrm{~kg} / \mathrm{m}^{2}$ ); ${ }^{16}$ WC (normal when $<80$ for women and $<94 \mathrm{~cm}$ for men and increased when $\geq 80 \mathrm{~cm}$ for women and $\geq 94 \mathrm{~cm}$ for men); ${ }^{16}$ waist-to-height ratio (normal when $<0.52$ for men and $<0.53$ for women and increased when $\geq 0.52$ for men and $\geq 0.53$ for women) $;^{17}$ and food security evaluated using the Brazilian Food and Nutritional Insecurity Scale, ${ }^{18}$ which enabled classifying the homes into the following categories: food security, mild food insecurity and moderate/ severe food insecurity.

Blood samples were collected through a venous puncture after a 10-hour fast. The analyses to determine the levels of fasting blood glucose, triglycerides, and total cholesterol used the Accutrend GCT [Roche Diagnóstica, Brazil], which allows immediate readings. The components of the biochemical profile were fasting blood glucose [normal when $<100 \mathrm{mg} / \mathrm{dL}$ and reduced glucose tolerance/diabetes mellitus (DM) when $\geq 100 \mathrm{mg} / \mathrm{dL}$ or when the individual used a hypoglycemic medication], ${ }^{19}$ triglycerides (normal when $<150 \mathrm{mg} / \mathrm{dL}$ and high when $\geq 150 \mathrm{mg} / \mathrm{dL}$ ), ${ }^{20}$ and total cholesterol (normal when $<190 \mathrm{mg} / \mathrm{dL}$ and high when $\geq 190 \mathrm{mg} / \mathrm{dL}$ ). ${ }^{20}$

Regarding the outcome variable, blood pressure (BP) was measured in duplicate using the auscultation method (Glicomed $^{\text {TM }}$ sphygmomanometer, model CE-0483), followed by the calculation of the arithmetic mean of the results. The procedures to prepare the individuals for BP measurement followed the recommendations of the Brazilian Society of Cardiology: ${ }^{6}$ make sure that the individual rested for at least five minutes in a calm environment; did not have a full bladder, had not practiced physical exercise in the previous 60 minutes, had not consumed alcohol, coffee, or food in the previous hour, and had not smoked in the previous 30 minutes; and was seated at the time of the measurement, with the legs uncrossed, feet flat on the floor, and arm at the height of the heart. The criteria to diagnose hypertension was based on the Seventh Brazilian Hypertension Guidelines, ${ }^{6}$ which classify an individual with hypertension when the systolic BP is $\geq 140$ and/or diastolic BP is $\geq 90$. We also considered hypertensive individuals who declared having a previous diagnosis and were under treatment with antihypertensive medications. 
The data used in the present investigation derived from a study entitled "Evaluation of food and nutritional security in urban and rural communities affected by drought in the semi-arid region of Pernambuco" (certificate of presentation for ethical approval: 38878814.9.0000.5208; certificate of approval: 897.655). All participants received information about the study and signed the informed consent form.

\section{Statistical analysis}

All data were entered twice with the Epi Info ${ }^{\mathrm{TM}}$ software, version 6.04 (CDC/WHO, Atlanta, GE, USA), with the subsequent use of the VALIDATE module to check data consistency. We grouped the explanatory variables into the following four hierarchically ordered levels from distal to proximal: 1) biological factors; 2) demographic and socioeconomic factors; 3) behavioral factors, and 4) biochemical and nutritional factors (proximal level). Based on a conceptual model to determine hypertension, we assumed that predisposing factors imply different hierarchical levels of determination.

We conducted univariate statistical analysis with either Pearson's chi-square test or the chi-square test for trend to establish associations between explanatory variables and the outcome. Variables with a p-value $<0.20$ were incorporated into the multivariate analysis using Poisson regression with robust variance. Results of the univariate analysis were expressed as percentages and respective $95 \%$ confidence intervals $(95 \% \mathrm{Cl})$ and of the multivariate analysis were described as prevalence ratios and respective $95 \% \mathrm{Cl}$. A p-value $<0.05$ in the final model was considered indicative of a statistically significant association. All analyses had the aid of the Statistical Package for Social Sciences (SPSS), version 13.0 (IBM Analytics, NC, USA) and Stata, version 14.0 (StataCorp, TX, USA).

\section{Results}

The final sample consisted of 416 adults with a median age of 35.0 (interquartile range of 28.0 to 48.0 ) years. Most of the sample was female $(64 ; 9 \%, 95 \% \mathrm{Cl}: 60.1$ to 69.5$)$, of black/ multiracial ethnicity $(78.4 \%, 95 \% \mathrm{Cl}: 74.0$ to 82.2$)$, and lived in urban areas $(57.9 \%, 95 \% \mathrm{Cl}$ : 53.0 to 62.7$)$.

A total of $19.7 \%(95 \% \mathrm{Cl}: 16.1$ to 23.9$)$ of the sample had the habit of consuming alcoholic beverages, $23.3 \%$ (95\%Cl: 19.4 to 27.7$)$ smoked actively, $16.3 \%(95 \% \mathrm{Cl}: 13.0$ to 20.3$)$ smoked passively, and $71.5 \%(95 \% \mathrm{Cl}: 65.6$ to 76.9$)$ were sedentary or insufficiently active. Moreover, $10.1 \%$ (95\% Cl: 7.5 to 13.5$)$ of the sample reported adding salt to food after preparation sometimes or nearly always.

The prevalence of hypertension was $27.4 \%$ (95\% Cl: 23.2 to 32.0). Table 1 shows the distribution of the condition according to demographic and socioeconomic variables. We found a statistically significant association between higher prevalence of hypertension and increasing age and lower levels of schooling and income. Regarding behavioral variables (Table 2), hypertension was more frequent among active smokers/ex-smokers and passive smokers. With respect to the health and nutritional profile (Table 3), hypertension was associated with overweight, determined by the BMI, and an increased weight-to-height ratio. Hypertension was also associated with the following biochemical variables: reduced glucose tolerance/DM and high total cholesterol (Table 4).
After statistical adjustments in the hierarchical model, the explanatory variables that remained significantly associated with hypertension were age, economic class, active smoking, BMI, and fasting blood glucose (Table 5).

\section{Discussion}

Hypertension is one of the most common conditions among older adults, but it also affects a considerable portion of the adult population (20 to 59 years), striking more than 30 million individuals in this age range in Brazil alone. ${ }^{6}$ Thus, addressing this condition in the adult population is necessary.

Although slightly lower than the estimated national average of $30 \%$, ${ }^{6}$ the prevalence of hypertension among adults in the semi-arid region of Pernambuco was high, confirming that this is a serious public health problem. This finding was expected, given the low socioeconomic development of the mesoregion and its possible association with the high prevalence of chronic non-communicable diseases. ${ }^{10}$ We underline, however, that some individuals classified as hypertensive may actually have "white coat hypertension," which was not evaluated and could be considered a limitation of the present study.

According to Andrade et al., ${ }^{8}$ the prevalence of selfreported hypertension among adults in Northeastern Brazil is $19.4 \%$ (95\% Cl: 18.4 to 20.5$)$, which is lower than the rate found in the present study. This divergence may be explained by one of the limitations of using self-reports, which, although validated in population-based studies, might underestimate prevalence rates. ${ }^{21}$ This aspect is influenced by the access to and use of health care services by the part of the population investigated, as self-reported hypertension would require a previous medical diagnosis. ${ }^{21}$

The greater susceptibility to hypertension with the increase in age found in the present study has been reported in the specialized literature, and there is a consensus on the direct, linear relationship between BP and age. ${ }^{6}$ This relationship results from the development of atherosclerosis, with the stiffening of the arteries leading to an elevation in pressure levels, which is normally caused by physiological changes stemming from the aging process. ${ }^{22}$

The association between economic class and hypertension in the present study supports the conjecture that individuals with low status are more vulnerable to the development of the disease. ${ }^{23}$ Furthermore, despite the association with a low level of schooling having lost its significance in the multivariate model, it could represent a more evident risk factor than income. ${ }^{23}$ Thus, it is important to increase the monitoring of and care for these more vulnerable groups.

Being a smoker or ex-smoker was also associated with the prevalence of hypertension, which corroborates data from other population-based studies conducted in Brazil and a review study by Passos et al. ${ }^{21}$ This result is consistent with experimental evidence that smoking can cause hypertension and other cardiovascular diseases. ${ }^{24}$ In the first decade of the $21^{\text {st }}$ century, $11 \%$ of worldwide deaths from cardiovascular diseases were attributed to smoking, ${ }^{25}$ making this habit an important risk factor to address in health promotion and disease prevention actions. 


\section{Original Article}

Table 1 - Distribution of systemic arterial hypertension according to demographic and socioeconomic characteristics in adults from the semi-arid region, state of Pernambuco, Brazil, 2015

\begin{tabular}{|c|c|c|c|c|}
\hline \multirow[b]{2}{*}{ Variables } & \multicolumn{3}{|c|}{ Systemic arterial hypertension } & \multirow[b]{2}{*}{$\mathrm{p}$-value } \\
\hline & $\mathrm{n}$ & $\%$ & $95 \% \mathrm{Cl}$ & \\
\hline Gender & & & & 0.358 \\
\hline Male & 44 & 30.1 & $22.8-38.3$ & \\
\hline Female & 70 & 25.9 & $20.8-31.6$ & \\
\hline Age (years) & & & & $0.000^{\S}$ \\
\hline $20-29$ & 13 & 10.6 & $05.7-17.4$ & \\
\hline $30-39$ & 20 & 15.9 & $10.0-23.4$ & \\
\hline $40-49$ & 25 & 36.8 & $25.4-49.3$ & \\
\hline $50-59$ & 56 & 56.6 & $46.2-66.5$ & \\
\hline Ethnicity & & & & 0.721 \\
\hline White & 26 & 28.9 & $19.8-39.4$ & \\
\hline Multiracial or black & 88 & 27.0 & $22.3-32.2$ & \\
\hline Schooling & & & & $0.000^{\S}$ \\
\hline Never studied & 66 & 44.6 & $36.4-53.0$ & \\
\hline Primary school & 32 & 19.5 & $13.7-26.4$ & \\
\hline High school/university & 16 & 15.4 & $09.1-23.8$ & \\
\hline Employment status & & & & 0.150 \\
\hline Works & 45 & 23.9 & $18.0-30.7$ & \\
\hline Does not work & 69 & 30.3 & $24.4-36.7$ & \\
\hline \multicolumn{5}{|l|}{ Place of residence } \\
\hline Urban area & 65 & 27.0 & $21.5-33.0$ & 0.816 \\
\hline Rural area & 49 & 28.0 & $21.5-35.3$ & \\
\hline Economic class & & & & 0.001 \\
\hline Upper or middle* & 45 & 20.5 & $15.3-26.4$ & \\
\hline Lower $^{\dagger}$ & 69 & 35.2 & $28.5-42.3$ & \\
\hline
\end{tabular}

95\% Cl: $95 \%$ confidence interval; " classes A1, A2, B1, B2, C1, and C2; ${ }^{\prime}$ classes $D$ and $E ; ~ \ddagger P$ Pearson's chi-square test; ${ }^{\S}$ chi-square test for trend.

Body composition is another important aspect related to hypertension, especially with regard to fat distribution, as the increase in visceral adipose tissue is directly associated with a greater incidence of the disease. ${ }^{26}$ One of the limitations of the present study was not evaluating body fat distribution based on more accurate methods, such as the quantification of visceral or subcutaneous adipose tissue using computed tomography. ${ }^{27}$ However, studies report that indicators such as BMI and WC are good tools to use in population-based studies and increases in these measures are associated with a higher risk of developing hypertension. ${ }^{28-30}$

The positive association between overweight based on $\mathrm{BMI}$ and hypertension in the semi-arid region of Pernambuco underscores the need for more effective dietary and nutritional education programs derived from health promotion policies and actions, in addition to greater encouragement to practice physical activity. Strategies of this nature would have a higher impact on the process of nutritional transition that has affected the country ${ }^{31}$ and culminated in a $26.3 \%$ increase in overweight between 2006 and 2016, according to a telephone survey conducted by the Brazilian Ministry of Health. ${ }^{32}$

The concomitant occurrence of hypertension and reduced glucose tolerance and/or DM supports the scientific evidence indicating the close link between these conditions, which often develop together and through the same metabolic pathways. ${ }^{33}$ An analysis of the Brazilian National Household Surveys conducted in 1998, 2003, and 2008 shows an increase from 1.7 to $2.8 \%$ in the prevalence coefficient standardized by gender and age range for DM associated with hypertension in the period, especially in the northeast and midwest regions of the country. ${ }^{34}$ These data further highlight the considerable problems these conditions represent, especially in regions such as Northeastern Brazil and mesoregions such as the semi-arid region. 
Table 2 - Distribution of systemic arterial hypertension according to behavioral characteristics in adults from the semi-arid region, state of Pernambuco, Brazil, 2015

\begin{tabular}{|c|c|c|c|c|}
\hline \multirow{2}{*}{ Variables } & \multicolumn{3}{|c|}{ Systemic arterial hypertension } & \multirow{2}{*}{$p$-value ${ }^{\S}$} \\
\hline & $\mathrm{n}$ & $\%$ & $95 \% \mathrm{Cl}$ & \\
\hline Alcohol intake* & & & & 0.330 \\
\hline Yes & 26 & 31.7 & $21.9-42.9$ & \\
\hline No & 88 & 26.3 & $21.8-31.5$ & \\
\hline Active smoking & & & & 0.000 \\
\hline Smoker or ex-smoker & 54 & 55.7 & $45.2-65.8$ & \\
\hline Never smoked & 60 & 18.8 & $14.8-23.6$ & \\
\hline Passive smoking ${ }^{\dagger}$ & & & & 0.000 \\
\hline Yes & 32 & 47.1 & $34.8-59.6$ & \\
\hline No & 82 & 23.6 & $19.3-28.4$ & \\
\hline Sedentary or insufficiently active & 61 & 32.4 & $25.8-39.6$ & \\
\hline Active or very active & 33 & 44.0 & $32.5-55.9$ & \\
\hline Addition of salt to food & & & & 0.200 \\
\hline Never & 106 & 28.3 & $23.9-33.3$ & \\
\hline Sometimes or almost always & 8 & 19.0 & $08.6-34.1$ & \\
\hline
\end{tabular}

95\% Cl: 95\% confidence interval; * considering the 30 days prior to data collection; ${ }^{\dagger}$ individuals who do not actively smoke but are frequently in contact with cigarette smoke from people at home, work, or school/university; ${ }^{\ddagger}$ classified using the International Physical Activity Questionnaire (IPAQ); § Pearson's chi-square test.

Table 3 - Distribution of systemic arterial hypertension according to health and nutritional characteristics in adults from the semi-arid region, state of Pernambuco, Brazil, 2015

\begin{tabular}{|c|c|c|c|c|}
\hline \multirow{2}{*}{ Variables } & \multicolumn{3}{|c|}{ Systemic arterial hypertension } & \multirow{2}{*}{$p$-value ${ }^{* \star}$} \\
\hline & $\mathrm{n}$ & $\%$ & $95 \% \mathrm{Cl}$ & \\
\hline $\mathrm{BMI}$ & & & & 0.019 \\
\hline Not overweight & 29 & 19.9 & $13.7-27.3$ & \\
\hline Overweight $^{\dagger}$ & 76 & 30.6 & $25.0-36.8$ & \\
\hline WC & & & & 0.082 \\
\hline Normal ${ }^{\ddagger}$ & 29 & 21.8 & $15.1-29.8$ & \\
\hline Increased $\$$ & 81 & 30.0 & $24.6-35.8$ & \\
\hline Waist-to-height ratio & & & & 0.012 \\
\hline Normal ${ }^{\prime /}$ & 17 & 17.0 & $10.2-25.8$ & \\
\hline Increased ${ }^{\pi}$ & 87 & 29.8 & $24.6-35.4$ & \\
\hline Food security ${ }^{\#}$ & & & & $0.245^{\text {tt }}$ \\
\hline Food security & 35 & 34.0 & $24.9-44.0$ & \\
\hline Mild food insecurity & 33 & 23.7 & $16.9-31.7$ & \\
\hline Moderate or severe food insecurity & 46 & 26.4 & $20.1-33.6$ & \\
\hline
\end{tabular}

The lack of associations between hypertension and alcohol intake, sedentary lifestyle, and the addition of salt to food after preparation was an unexpected finding, as these aspects are traditionally considered risk factors for the disease. ${ }^{6}$ This paradox may be attributed to reverse causality, which consists of the repercussion of a disease positively changing the behavior of individuals, as many respondents were aware of their hypertension at the time of data collection. Another possible explanation for the lack of such associations would be the sample size, which was 


\section{Original Article}

Table 4 - Distribution of systemic arterial hypertension according to biochemical variables in adults from the semi-arid region, state of Pernambuco, Brazil, 2015

\begin{tabular}{|c|c|c|c|c|}
\hline \multirow{2}{*}{ Variables } & \multicolumn{3}{|c|}{ Systemic arterial hypertension } & \multirow{2}{*}{ p-value } \\
\hline & $\mathrm{n}$ & $\%$ & $95 \% \mathrm{Cl}$ & \\
\hline Fasting blood glucose & & & & 0.000 \\
\hline Normal" & 56 & 28.4 & $22.2-35.3$ & \\
\hline Reduced glucose tolerance and/or $\mathrm{DM}^{\dagger}$ & 30 & 68.2 & $52.4-81.4$ & \\
\hline Triglycerides & & & & 0.416 \\
\hline Normal $\left.\right|^{\ddagger}$ & 32 & 32.7 & $23.5-42.9$ & \\
\hline $\mathrm{High}^{\S}$ & 54 & 37.8 & $29.8-46.2$ & \\
\hline Total cholesterol & & & & 0.005 \\
\hline Normal $^{\prime \prime}$ & 27 & 25.7 & $17.7-35.2$ & \\
\hline High" $^{\pi}$ & 59 & 43.4 & $34.9-52.1$ & \\
\hline
\end{tabular}

95\% Cl: 95\% confidence interval; DM: diabetes mellitus; " $<100 \mathrm{mg} / \mathrm{dL} ;{ }^{\dagger} \geq 100 \mathrm{mg} / \mathrm{dL}$ or when hypoglycemic medication was used; ${ }^{\ddagger}<150 \mathrm{mg} / \mathrm{dL} ;{ }^{\S} \geq 150 \mathrm{mg} / \mathrm{dL}$;

" $<190 \mathrm{mg} / \mathrm{dL} ; \pi^{\Pi \geq} 190 \mathrm{mg} / \mathrm{dL} ; "$ Pearson's chi-square test.

Table 5 - Crude and adjusted prevalence ratios for systemic arterial hypertension according to explanatory variables in adults from the semiarid region, state of Pernambuco, Brazil, 2015

\begin{tabular}{|c|c|c|c|c|c|c|}
\hline \multirow{3}{*}{ Variables } & \multirow{3}{*}{$\mathrm{n}$} & \multicolumn{4}{|c|}{ Systemic arterial hypertension } & \multirow{3}{*}{ p-value } \\
\hline & & \multicolumn{2}{|c|}{ Crude analysis } & \multicolumn{2}{|c|}{ Adjusted analysis } & \\
\hline & & PR & $95 \% \mathrm{Cl}$ & PR & $95 \% \mathrm{Cl}$ & \\
\hline \multicolumn{7}{|l|}{ Age (years) } \\
\hline $20-29$ & 13 & 1.00 & & 1.00 & & \\
\hline $30-39$ & 20 & 1.05 & $0.97-1.13$ & 1.05 & $0.97-1.13$ & 0.214 \\
\hline $40-49$ & 25 & 1.24 & $1.12-1.36$ & 1.24 & $1.12-1.36$ & 0.000 \\
\hline $50-59$ & 56 & 1.42 & $1.31-1.53$ & 1.42 & $1.31-1.53$ & 0.000 \\
\hline \multicolumn{7}{|l|}{ Economic class" } \\
\hline Upper or middle & 45 & 1.00 & & 1.00 & & \\
\hline Lower & 69 & 1.12 & $1.05-1.20$ & 1.09 & $1.02-1.17$ & 0.007 \\
\hline \multicolumn{7}{|l|}{ Active smoking ${ }^{\dagger}$} \\
\hline Never smoked & 54 & 1.00 & & 1.00 & & \\
\hline Smoker or ex-smoker & 60 & 1.31 & $1.22-1.41$ & 1.11 & $1.02-1.22$ & 0.023 \\
\hline \multicolumn{7}{|l|}{$\mathrm{BM}^{\ddagger}$} \\
\hline Not overweight & 29 & 1.00 & & 1.00 & & \\
\hline Overweight & 76 & 1.09 & $1.02-1.17$ & 1.21 & $1.07-1.37$ & 0.003 \\
\hline \multicolumn{7}{|l|}{ Fasting blood glucose $\mathrm{e}^{\ddagger}$} \\
\hline Normal & 56 & 1.00 & & 1.00 & & \\
\hline Reduced glucose tolerance and/or DM & 30 & 1.31 & $1.19-1.44$ & 1.15 & $1.03-1.27$ & 0.012 \\
\hline
\end{tabular}

PR: prevalence ratio; $95 \% \mathrm{Cl}$ : 95\% confidence interval; BMI: body mass index; DM: diabetes mellitus; PR 1.00 - reference; 'adjusted for age, schooling, and employment status; ${ }^{\dagger}$ adjusted for age, schooling, employment status, economic class, passive smoking, and physical activity level; ${ }^{\ddagger}$ adjusted for age, schooling, employment status, economic class, passive smoking, physical activity level, BMI, WC, waist-to-height ratio, and fasting blood glucose; § Poisson regression with robust variance.

calculated only to estimate the prevalence of the outcome, possibly limiting the robustness of sub-analyses. Also, the predominance of females in the present study may have been due to the sampling method adopted.

The cross-sectional design constitutes another limitation of the present study by not allowing the inference of causality, as information on exposure and outcome are collected at the same time. However, this study makes important contributions to the knowledge about the epidemiology of hypertension in the population investigated. According to Vianna and Segall-Corrêa, ${ }^{35}$ initiatives such as the present study are important and necessary for the acquisition of previously 
unpublished information that can be used for regional, national, and international comparisons. Cross-sectional studies conducted in specific locations can provide better knowledge of local aspects, peculiarities, and risk factors that could go unnoticed in analyses involving broader territorial units, thereby complementing information on the geographic distribution of the disease.

\section{Conclusion}

The prevalence of hypertension was high in the semi-arid region studied and was associated with important risk factors, such as increasing age, low socioeconomic class, active smoking, overweight, and reduced glucose tolerance and/or DM. The constant monitoring of chronic non-communicable diseases, especially hypertension, DM, and obesity, and their associated factors is fundamental to the planning and continuous improvement of public health programs and actions, as well as the drafting of specific strategies for the region studied.

\section{Acknowledgments}

The authors thank the Fundação de Amparo à Ciência e Tecnologia do Estado de Pernambuco (FACEPE - Foundation for the Support of Science and Technology of the State of Pernambuco) for providing financial support for the present study.

\section{Author contributions}

Conception and design of the research: Santiago ERC, Oliveira JS, Leal VS, Lira PIC; Acquisition of data: Leal VS, Lira

\section{References}

1. James PA, Oparil S, Carter BL, Cushman WC, Dennison-Himmelfarb C, Handler J, et al. 2014 evidence-based guideline for the management of high blood pressure in adults: report from the panel members appointed to the Eighth Joint National Committee (JNC 8). JAMA. 2014;311(5):507-20.

2. World Health Organization. A global brief on hypertension: silent killer, global public health crisis: World Health Day 2013. Geneva: WHO; 2013.

3. Lim SS, Vos T, Flaxman AD, Danaei G, Shibuya K, Adair-Rohani H, et al. A comparative risk assessment of burden of disease and injury attributable to 67 risk factors and risk factor clusters in 21 regions, 1990-2010: a systematic analysis for the Global Burden of Disease Study 2010. Lancet. 2012;380(9859):2224-60.

4. Nobre F, Coelho EB, Lopes PC, Geleilete TJ. Hipertensão arterial sistêmica primária. Medicina (Ribeirao Preto Online). 2013;46(3):256-72.

5. Mills KT, Bundy JD, Kelly TN, Reed J, Kearney PM, Reynolds K, et al. Global disparities of hypertension prevalence and control: a systematic analysis of population-based studies from 90 countries. Circulation. 2016;134(6):441-50.

6. Malachias MVB, Brandão AAA, Kaiser S, Moreira Filho O. 7ª Diretriz Brasileira de Hipertensão Arterial: Capítulo 5 - Decisão e Metas Terapêuticas. Arq Bras Cardiol. 2016;107(3 supl 3):1-103.

7. Picon RV, Fuchs FD, Moreira LB, Riegel G, Fuchs SC. Trends in prevalence of hypertension in Brazil: a systematic review with meta-analysis. PLoS One. 2012;7(10):e48255
PIC; Analysis and interpretation of the data: Santiago ERC, Diniz AS, Oliveira JS, Leal VS; Statistical analysis: Santiago ERC, Andrade MIS; Obtaining financing: Diniz AS; Writing of the manuscript: Santiago ERC; Critical revision of the manuscript for intellectual content: Santiago ERC, Diniz AS, Oliveira JS, Leal VS, Andrade MIS, Lira PIC.

\section{Potential Conflict of Interest}

No potential conflict of interest relevant to this article was reported.

\section{Sources of Funding}

This study was funded by Fundação de Amparo à Ciência e Tecnologia do Estado de Pernambuco.

\section{Study Association}

This article is part of the thesis of master submitted by Emerson Rogério Costa Santiago, from Universidade Federal de Pernambuco.

\section{Ethics approval and consent to participate}

This study was approved by the Ethics Committee of the Universidade Federal de Pernambuco under the protocol number 897.655. All the procedures in this study were in accordance with the 1975 Helsinki Declaration, updated in 2013. Informed consent was obtained from all participants included in the study.
8. Andrade SSDA, Stopa SR, Brito AS, Chueri PS, Szwarcwald CL, Malta DC. Selfreported hypertension prevalence in the Brazilian population: analysis of the National Health Survey, 2013. Epidemiol Serv Saude. 2015;24(2):297-304

9. Galvão RRS, Soares DA. Prevalência de hipertensão arterial e fatores associados em adultos: uma revisão na literatura brasileira. APS. 2016;19(1):139-49.

10. Lyra R, Silva RDS, Montenegro Jr RM, Matos MVC, Cézar NJB, Maurícioda-Silva L. Prevalence of diabetes and associated factors in an urban adult population of low educational level and income from the Brazilian Northeast wilderness. Arq Bras Endocrinol Metabol. 2010;54(6):560-6.

11. Brasil. Ministério do Desenvolvimento Regional [internet]. Nova Delimitação do Semi-Árido Brasileiro; 2005. [acesso 1 out 2017]. Disponível em: http:// www.mi.gov.br/c/document library/get file?uuid=0aa2b9b5-aa4d-4b55a6e1-82faf0762763\&groupld $=24915$.

12. Instituto Brasileiro de Geografia e Estatística. Household Budget Survey 2002-2003: analysis of household food availability and nutritional status in Brazil. Rio de Janeiro: IBGE; 2004.

13. Associação Brasileira de Empresas de Pesquisa. Critério de Classificação Brasil[internet]. . [acesso em 01 out 2017]. Disponível em: http://www.abep. org/Servicos/Download.aspx?id=09.

14. Matsudo S, Araújo T, Matsudo V, Andrade D, Andrade E, Oliveira LC, et al International physical activity questionnaire (LPAQ): study of validity and reliability in Brazil. Rev Bras Ativ Fis Saude. 2012;6(2):5-18. 


\section{Original Article}

15. World Health Organization. Physical status: the use and interpretation of anthropometry. WHO Technical Report Series n. 854. Geneva: WHO; 1995.

16. World Health Organization. Obesity: Preventing and managing the global epidemic. WHO Techmical Report Series n. 894. Geneva: WHO; 2000.

17. Rodrigues SL, Baldo MP, Mill JG. Association of waist-stature ratio with hypertension and metabolic syndrome: population-based study. Arq Bras Cardiol. 2010;95(2):186-91.

18. Pérez-Escamilla R, Segall-Corrêa AM, Kurdian Maranha L, Sampaio Md Mde F, Marín-León L, Panigassi G. An adapted version of the U.S. Department of Agriculture Food Insecurity module is a valid tool for assessing household food insecurity in Campinas, Brazil. J Nutr. 2004;134(8):1923-8.

19. Milech A, Angelucci AP, Golbert A, Carrilho AJ, Ramalho AC, Aguiar AC, et al. Diretrizes da Sociedade Brasileira de Diabetes (2015-2016). São Paulo: AC Farmacêutica; 2016.

20. Faludi AA, Izar MCDO, Saraiva JFK, Chacra APM, Bianco HT, Afiune Neto A, et al. Atualização da Diretriz Brasileira de Dislipidemias e Prevenção da Aterosclerose-2017. Arq Bras Cardiol. 2017;109(2 Supl 1):1-76.

21. Passos VMDA. Assis TD, Barreto SM. Hipertensão arterial no Brasil: estimativa de prevalência a partir de estudos de base populacional. Epidemiol Serv Saude. 2006;15(1):35-45.

22. McEniery CM, Wilkinson IB, Avolio AP. Age, hypertension and arterial function. Clin Exp Pharmacol Physiol. 2007;34(7):665-71.

23. Leng B, Jin $Y, L i G$, Chen L, Jin N. Socioeconomic status and hypertension: a meta-analysis. J Hypertens. 2015;33(2):221-9.

24. Talukder MAH, Johnson WM, Varadharaj S, Lian J, Kearns PN, El-Mahdy MA, et al. Chronic cigarette smoking causes hypertension, increased oxidative stress, impaired NO bioavailability, endothelial dysfunction, and cardiac remodeling in mice. Am J Physiol Heart Circ Physiol. 2010;300(1):H388-96.

25. Ezzati M, Henley SJ, Thun MJ, Lopez AD. Role of smoking in global and regional cardiovascular mortality. Circulation. 2005;112(4):489-97.
26. Chandra A, Neeland IJ, Berry JD, Ayers CR, Rohatgi A, Das SR, et al. The relationship of body mass and fat distribution with incident hypertension: observations from the Dallas Heart Study. J Am Coll Cardiol. 2014;64(10):997-1002.

27. Pinho CPS, Diniz AS, de Arruda IKG, Leite APDL, Rodrigues IG. Effects of weight loss on adipose visceral and subcutaneous tissue in overweight adults. Clin Nutr. 2017;37(4):1252-8.

28. Shihab HM, Meoni LA, Chu AY, Wang NY, Ford DE, Liang KY, et al. Body mass index and risk of incident hypertension over the life course: the Johns Hopkins Precursors Study. Circulation. 2012;126(25):2983-9.

29. Bombelli M, Facchetti R, Sega R, Carugo S, Fodri D, Brambilla G, et al. Impact of body mass index and waist circumference on the long-term risk of diabetes mellitus, hypertension, and cardiac organ damage. Hypertension. 2011;58(6):1029-35.

30. Pinho CPS, Diniz ADS, de Arruda IKG, Leite APDL, Petribú MMV, Rodrigues IG. Predictive models for estimating visceral fat: The contribution from anthropometric parameters. PLOS One. 2017;12(7):e0178958.

31. Batista Filho M, Rissin A. Nutritional transition in Brazil: geographic and temporal trends. Cad Saude Publica. 2003;19(Suppl 1):S181-91.

32. Brasil. Ministério da Saúde. Vigitel Brasil 2016: vigilância de fatores de risco e proteção para doenças crônicas por inquérito telefônico : estimativas sobre frequência e distribuição sociodemográfica de fatores de risco e proteção para doenças crônicas nas capitais dos 26 estados brasileiros e no Distrito Federal em 2016 [internet]. [acesso em 11 maio 2018]. Disponível em: http://portalarquivos2. saude.gov.br/images/pdf/2018/marco/02/vigitel-brasil-2016.pdf.

33. Cheung BMY, LiC. Diabetes and hypertension: is there a common metabolic pathway?. Curr Atheroscler Rep. 2012;14(2):160-6.

34. Freitas LRS, Garcia LP. Evolution of prevalence of diabetes and associated hypertension in Brazil: analysis of National Household Sample Survey, 1998, 2003 and 2008. Epidemiol Serv Saude. 2012;21(1):7-19.

35. Vianna RPT, Segall-Corrêa AM. Household food insecurity in municipalities of the Paraíba State, Brazil. Rev Nutr. 2008;21(Suppl 0):111-22. 
